\title{
Downward transport of ozone rich air and implications for atmospheric chemistry in the Amazon rainforest
}

Tobias Gerken ${ }^{\mathrm{a}, *}$, Dandan $\mathrm{Wei}^{\mathrm{a}}$, Randy J. Chase ${ }^{\mathrm{a}}$, Jose D. Fuentes ${ }^{\mathrm{a}}$, Courtney Schumacher $^{\mathrm{f}}$, Luiz A. T. Machado ${ }^{\mathrm{d}}$, Rita V. Andreolie, Marcelo Chamecki ${ }^{\mathrm{a}}$, Rodrigo A. Ferreira de Souza ${ }^{e}$, Livia S. Freire ${ }^{\mathrm{a}}$, Angela B. Jardine ${ }^{\mathrm{c}}$, Antonio O. Manzi ${ }^{\mathrm{c}}$, Rosa M. Nascimento dos Santos ${ }^{\mathrm{e}}$, Celso von Randow ${ }^{\mathrm{d}}$, Patrícia dos Santos Costa ${ }^{\mathrm{e}, \mathrm{c}}$, Paul C. Stoy ${ }^{\mathrm{g}}$, Julio Tótah ${ }^{\text {, Amy M. Trowbridgeg,i }}$

${ }^{a}$ Department of Meteorology, The Pennsylvania State University, University Park, PA, USA

${ }^{b}$ Department of Earth Sciences, The College at Brockport State University of New York, Brockport, NY, USA

${ }^{c}$ Climate and Environment Department, Instituto Nacional de Pesquisas da Amazônia (INPA), Manaus, AM, Brasil

${ }^{d}$ Instituto Nacional de Pesquisas Espaciais (INPE), Saõ José dos Campos, SP, Brazil

${ }^{e}$ Universidade do Estado do Amazonas, Manaus, AM, Brazil

${ }^{f}$ Department of Atmospheric Sciences, Texas A\&M University, College Station, TX, USA

${ }^{g}$ Department of Land Resources $\&$ Environmental Sciences, Montana State University, Bozeman, MT, USA

${ }^{h}$ Universidade Federal do Oeste do Pará, Santarém, PA, Brazil

${ }^{i}$ Department of Biology, Indiana University, Bloomington, IN, USA

\section{Abstract}

From April 2014 to January 2015, ozone $\left(\mathrm{O}_{3}\right)$ dynamics were investigated as part of GoAmazon 2014/5 project in the central Amazon rainforest of Brazil. Just above the forest canopy, maximum hourly $\mathrm{O}_{3}$ mixing ratios averaged $20 \mathrm{ppbv}$ (parts per billion on a volume basis) during the June-September dry months and 15 ppbv during the wet months. Ozone levels occasionally exceeded 75 ppbv in response to influences from biomass burning and regional air pollution. Individual convective storms transported $\mathrm{O}_{3}$-rich air parcels from the mid-troposphere to the surface and abruptly enhanced the regional atmospheric boundary layer by as much as 25 ppbv. In contrast to the individual storms, days with multiple convective systems produced successive, cumulative ground-level $\mathrm{O}_{3}$ increases. The magnitude of $\mathrm{O}_{3}$ enhancements depended on the vertical distribution of $\mathrm{O}_{3}$ within storm downdrafts and origin of downdrafts in the troposphere. Ozone mixing ratios remained enhanced for

\footnotetext{
${ }^{*}$ Corresponding author

Email address: tobias.gerken@psu.edu (Tobias Gerken)
} 
$>2$ hours following the passage of storms, which enhanced chemical processing of rainforestemitted isoprene and monoterpenes. Reactions of isoprene and monoterpenes with $\mathrm{O}_{3}$ are modeled to generate maximum hydroxyl radical formation rates of $6 \times 10^{6}$ radicals $\mathrm{cm}^{-3} \mathrm{~s}^{-1}$. Therefore, one key conclusion of the present study is that downdrafts of convective storms are estimated to transport enough $\mathrm{O}_{3}$ to the surface to initiate a series of reactions that reduce the lifetimes of rainforest-emitted hydrocarbons.

\section{Keywords: Isoprene, monoterpenes, air chemistry, convection, mesoscale}

\section{convective storms}

\section{Introduction}

Ozone $\left(\mathrm{O}_{3}\right)$ mixing ratios in the atmospheric boundary layer of the remote Amazon region remain mostly below 40 parts per billion on a per volume basis (ppbv) during the wet period (e.g., Bela et al., 2015; Gregory et al., 1988). Low $\mathrm{O}_{3}$ mixing ratios result from the reduced photochemistry associated with copious amounts of cloud cover and precipitation that limit actinic irradiance reaching near the surface ( $\mathrm{Gu}$ et al., 2002). In the absence of biomass burning, nitrogen oxides $\left(\mathrm{NO}_{\mathrm{X}}=\right.$ nitric oxide $(\mathrm{NO})$ plus nitrogen dioxide $\left.\left(\mathrm{NO}_{2}\right)\right)$, which are the key $\mathrm{O}_{3}$ precursors, only exist in trace mixing ratios in the atmospheric boundary layer (Torres and Buchan, 1988) because local soil emissions are small due to characteristically moist conditions. In the troposphere over the Amazon, $\mathrm{O}_{3}$ mixing ratios monotonically increase with altitude (Kirchhoff et al., 1990). Ozone profile changes result from convection (e.g., Folkins et al., 2002; Folkins and Martin, 2005), enhanced formation in the upper troposphere due to the presence of $\mathrm{NO}_{\mathrm{X}}$ from lightening (Goldenbaum and Dickerson, 1993; Thompson et al., 1997; Zhang et al., 2003), and surface deposition (Sigler et al., 2002).

Deep and moist convection is an important feature governing the distribution of trace gases and aerosols in the tropical troposphere (Garstang et al., 1988; Scala et al., 1990). Due to the internal dynamics of convective storms that have well defined updraft and downdraft regions, trace gases undergo frequent vertical redistribution in the troposphere. Within the storm updraft, boundary layer air is swiftly transported to the free troposphere where reactions of hydrocarbons, $\mathrm{NO}_{\mathrm{X}}$, and free radicals (such as hydroxyl radical, $\mathrm{HO}$ ) can en- 
hance oxidant and aerosol formation (Bertram et al., 2007). In contrast, within the storm downdraft, mid-tropospheric air parcels are transported towards the ground surface with reduced moisture content, lower equivalent potential temperature $\left(\theta_{e}\right)$ (Zipser, 1969, 1977), and higher ( $\geq 30 \mathrm{ppbv}$ ) $\mathrm{O}_{3}$ content (Betts et al., 2002). While earlier studies (Garstang et al., 1988; Thompson et al., 1997; Pickering et al., 1996) examined the transport of trace gases from the surface into the free troposphere by mesoscale convective systems (MCS), more recent investigations (e.g., Betts et al., 2002; Grant et al., 2008; Hu et al., 2010; Sahu and Lal, 2006) indicated that convective-type storms also transport $\mathrm{O}_{3}$-rich air from the mid-troposphere to the Earth's surface. In the areas impacted by the downdraft region of convective storms, driven by evaporative cooling from falling precipitation, ground-level $\mathrm{O}_{3}$ can abruptly increase due to the rapidly moving air parcels from layers aloft where $\mathrm{O}_{3}$ levels are much higher than at the surface. Ground-level $\mathrm{O}_{3}$ can increase by up to $30 \mathrm{ppbv}$ and the magnitude of these $\mathrm{O}_{3}$ enhancements depends on the propagation velocity of MCS and origin of downdrafts within storms (Grant et al., 2008) and the tropospheric $\mathrm{O}_{3}$ distribution, which can exhibit considerable day-to-day vertical variation in the Amazon (Kirchhoff et al., 1990).

In the Amazon region, maximum cloud cover and precipitation occur in the afternoon and early evening (Machado et al., 2004). Storms, with rainfall rates that can exceed $50 \mathrm{~mm} \mathrm{~h}^{-1}$, vary in their organization from locally occurring systems to basin scale convection and squall lines (Greco et al., 1990). As a consequence, storm downdraft dynamics depend on the overall state and type of the storm systems. In turn, the ground-level $\mathrm{O}_{3}$ enhancements associated with storms depend on the type of mesoscale convective systems. To date, these dynamics and their impact on atmospheric chemistry near the surface have rarely been explored.

The regional enhancement of $\mathrm{O}_{3}$ in the atmospheric boundary layer can influence several atmospheric chemical cycles. For example, during the daytime $\mathrm{O}_{3}$ can undergo photodissociation to produce excited oxygen atoms $\left(\mathrm{O}\left({ }^{1} \mathrm{D}\right)\right)$ that readily react with water vapor $\left(\mathrm{H}_{2} \mathrm{O}\right)$ to form $\mathrm{HO}$ (see reactions 1 and 2). The HO initiates the oxidation of biogenic volatile organic compounds (BVOCs), methane $\left(\mathrm{CH}_{4}\right)$, and carbon monoxide $(\mathrm{CO})$ (reactions 3 and 
4). Combined with the enhanced sink due to surface deposition, chemical reactions involving the $\mathrm{O}_{3}$ transported from the mid-troposphere reduce the greenhouse gas loading in the boundary layer ( $\mathrm{Hu}$ et al., 2010). In addition, elevated $\mathrm{O}_{3}$ mixing ratios can accelerate the oxidation rates of plant-emitted isoprene $\left(\mathrm{C}_{5} \mathrm{H}_{8}\right)$, monoterpenes $\left(\mathrm{C}_{10} \mathrm{H}_{16}\right)$, and sesquiterpenes $\left(\mathrm{C}_{15} \mathrm{H}_{24}\right)$. Reactions of BVOCs with $\mathrm{O}_{3}$ generate free radicals, acids, carbon dioxide, and $\mathrm{HO}$ (reactions 5-7). These photo-oxidation processes remain poorly understood but are of great importance in the Amazon basin because of the unusually strong source of BVOCs whose reaction products can lead to the formation of secondary organic aerosols (SOA) (Martin et al., 2010b) which can activate into cloud condensation nuclei (CCN) and thus influence cloud formation processes.

$$
\mathrm{O}_{3}+\mathrm{h} \nu \rightarrow \mathrm{O}_{2}+\mathrm{O}\left({ }^{1} \mathrm{D}\right)
$$

$$
\mathrm{O}\left({ }^{1} \mathrm{D}\right)+\mathrm{H}_{2} \mathrm{O} \rightarrow \mathrm{HO}+\mathrm{HO}
$$

$$
\mathrm{CH}_{4}+\mathrm{HO} \rightarrow \mathrm{CH}_{3}+\mathrm{H}_{2} \mathrm{O}
$$

$$
\mathrm{C}_{5} \mathrm{H}_{8}+\mathrm{O}_{3} \rightarrow \text { Products }+\mathrm{HO}
$$

$$
\mathrm{C}_{10} \mathrm{H}_{16}+\mathrm{O}_{3} \rightarrow \text { Products }+\mathrm{HO}
$$

$$
\mathrm{C}_{15} \mathrm{H}_{24}+\mathrm{O}_{3} \rightarrow \text { Products }+\mathrm{HO}
$$

Thus, the present work determines the magnitude and the frequency of ground-level $\mathrm{O}_{3}$ enhancements associated with convective systems in the central Amazon region of Brazil during April 2014 to January 2015. An additional objective is to investigate the storm attributes associated with downdraft events that enhanced ground-level $\mathrm{O}_{3}$. We also investigate the duration and the influences of ground-level $\mathrm{O}_{3}$ enhancements on atmospheric chemistry above the rainforest. Yields of $\mathrm{HO}$ from reactions entailing BVOCs and $\mathrm{O}_{3}$ are estimated to verify whether convective storms can measurably impact BVOC oxidation. 


\section{Methods}

\subsection{Study site characteristics}

The data used in this work were gathered during a field campaign at the Cuieiras Biological Reserve (S $2^{\circ} 36.11^{\prime}$, W $60^{\circ} 12.56^{\prime}$; managed by the Brazilian Institute of for Amazon Research - INPA) during April 2014 to January 2015 (Fuentes et al., in review). The study was part of the GoAmazon 2014/5 (Observations and Modeling of the Green Ocean Amazon) project, which designated the study site as T0k (also commonly referred to as ZF2). The reserve is located approximately $60 \mathrm{~km}$ north-north west of the City of Manaus, Amazonas, Brazil (Fig. 1). Due to prevailing easterly winds, air masses arriving at the site mostly come from areas with little human influence and show low aerosol concentrations (Martin et al., 2010a; Artaxo et al., 2013). However, the study site occasionally experiences the influences of Manaus' urban plume and biomass burning events that occur frequently during the dry season and are caused by both natural (e.g., lightning) and anthropogenic processes (e.g., deforestation). The vegetation surrounding the site is a closed primary forest with maximum tree heights of $30-40 \mathrm{~m}$. Leaf area index is typically estimated between 6.1 and $7.3 \mathrm{~m}^{2} \mathrm{~m}^{-2}$ (Marques Filho et al., 2005; Tóta et al., 2012) depending on measurement technique and location. The forest covers valleys and plateaus with altitude differences of circa $60 \mathrm{~m}$. Soils in the valleys are more sandy, and vegetation in the valleys tends to be less dense and tall. A 50-m tower (known as K34) was used as a platform to deploy measurement systems. The tower is located on the top of a plateau where canopy height was approximately $36 \mathrm{~m}$.

\subsection{Ozone and meteorological measurements}

Nine sonic anemometers (model CSAT3, Campbell Scientific Inc, Logan, UT) were deployed on the tower to measure the three components of the wind speed $(\mathrm{u}, \mathrm{v}$, and $\mathrm{w})$ and the sonic virtual temperature. The sonic anemometer located at the canopy top (35 m) was used to determine wind speed and direction. Measurement frequency was $20 \mathrm{~Hz}$ and data were processed to generate 30-minute averages. Relative humidity and temperature (model HMP-155, Vaisala, Vantaa, Finland) were measured at $32 \mathrm{~m}$ above ground. Rainfall mea- 


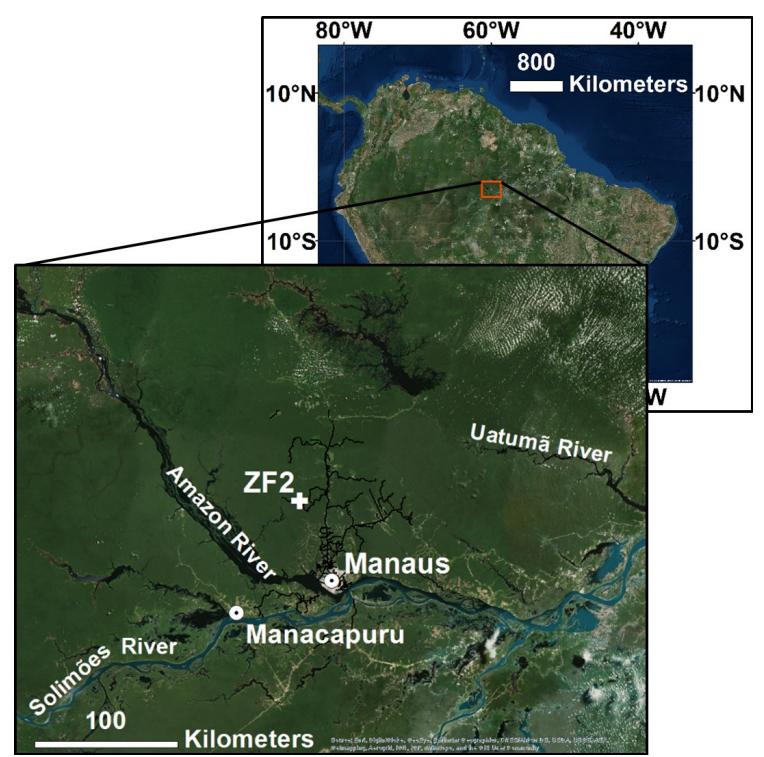

Figure 1: Map of South America and the central Amazon indicating the location of the study site (ZF2) in relationship to the cities of Manaus and Manacapuru. The black lines mark roads.

surements (model RIMB500, McVan Instruments, Melbourne, Australia) from a site located $3.11 \mathrm{~km}$ away from the flux tower are used in this analysis.

Ambient $\mathrm{O}_{3}$ levels were measured (model 49i, Thermo Fisher Scientific Inc., Waltham, MA) at a frequency of $1 \mathrm{~Hz}$. A Proton Transfer Reaction Mass Spectrometer (PTR-MS, Ionicon Analytik, Innsbruck, Austria) was used to measure isoprene and monoterpene mixing ratios. The air sampling intake for both instruments was placed at $40 \mathrm{~m}$ above ground. The inlet was placed below a rain shield and had a filter holder with a $1 \mu \mathrm{m}$ pore size Teflon membrane to exclude dust and pollen. The membrane was changed weekly. The $\mathrm{O}_{3}$ analyzer was housed in an environmentally controlled shed located at the ground level, approximately $5 \mathrm{~m}$ from the tower. A pump moved the air at 12 liters per minute from the inlet to the analyzer via a 3/8-inch $(9.8 \mathrm{~mm})$ outer diameter Teflon tube. The $\mathrm{O}_{3}$ analyzer was calibrated before deployment and regularly zeroed to ensure high data quality.

Ozone data were averaged to produce 5 - and 30-minute quantities. Air temperature $(T)$, water vapor mixing ratio $(r)$, and barometric pressure $(p)$ were used to compute values of 
equivalent potential temperature $\left(\theta_{e}\right)$

$$
\theta_{e} \approx\left(T+\frac{L_{v}}{c_{p d}} r\right)\left(\frac{p_{0}}{p}\right)^{\frac{R_{d}}{c_{p d}}}
$$

with the latent heat of vaporization $\left(L_{v}\right)$, the dry heat capacity of air $\left(c_{p d}\right)$, the gas constant of dry air $\left(R_{d}\right)$ and a reference pressure $\left(p_{0}\right)$ of $1000 \mathrm{hPa}$, to identify the periods when storm downdrafts occurred at the study site.

An automated algorithm detected $\mathrm{O}_{3}$ enhancement events that had to satisfy the criteria of an increase in 5-minute averaged $\mathrm{O}_{3}$ mixing ratio of at least $2.5 \mathrm{ppbv}$ and a simultaneous decrease in $\theta_{e}$ of $2.5 \mathrm{~K}$ within a one-hour time window. Local minimum and maximum values of $\mathrm{O}_{3}$ within the time window were used to determine start and end times of the enhancement events. After this automatic method, false detections were manually identified and removed. The average duration of $\mathrm{O}_{3}$ enhancement events was calculated to determine the periods when the atmospheric boundary layer was regionally enhanced with $\mathrm{O}_{3}$.

The GOES-13 (Geostationary Operational Environmental Satellites) satellite data were acquired through the Brazilian National Institute for Space Research (INPE) and used to investigate large-scale convection dynamics and extent. In addition, the Sistema de Proteção da Amazônia (SIPAM) operates a network of S-band (10-cm wavelength), Doppler radars with $500 \mathrm{~m}$ gate spacing and a $1.8^{\circ}$ beam width across the Amazon. One of SIPAM's radars is located at the Manaus airport $\left(03^{\circ} 08.98^{\prime} \mathrm{S}, 59^{\circ} 59.48^{\prime} \mathrm{W}\right.$, elevation $\left.102.4 \mathrm{~m}\right)$. The operational scan strategy had 17 elevation angles every 12 minutes and data were recorded for scans extending $250 \mathrm{~km}$ from the radar site. The radar data were analyzed to develop the threedimensional structure of storms impacting the ZF2 site.

\section{Results and discussion}

\subsection{Seasonal ozone dynamics}

Ozone mixing ratios at the rainforest study site differed between the wet and dry months (Fig. 2). After the end of the wet months (precipitation $>5 \mathrm{~mm} \mathrm{~d}^{-1}$ ) in June, $\mathrm{O}_{3}$ mixing ratios started to increase as revealed by median and maximum mixing ratios. Maximum 

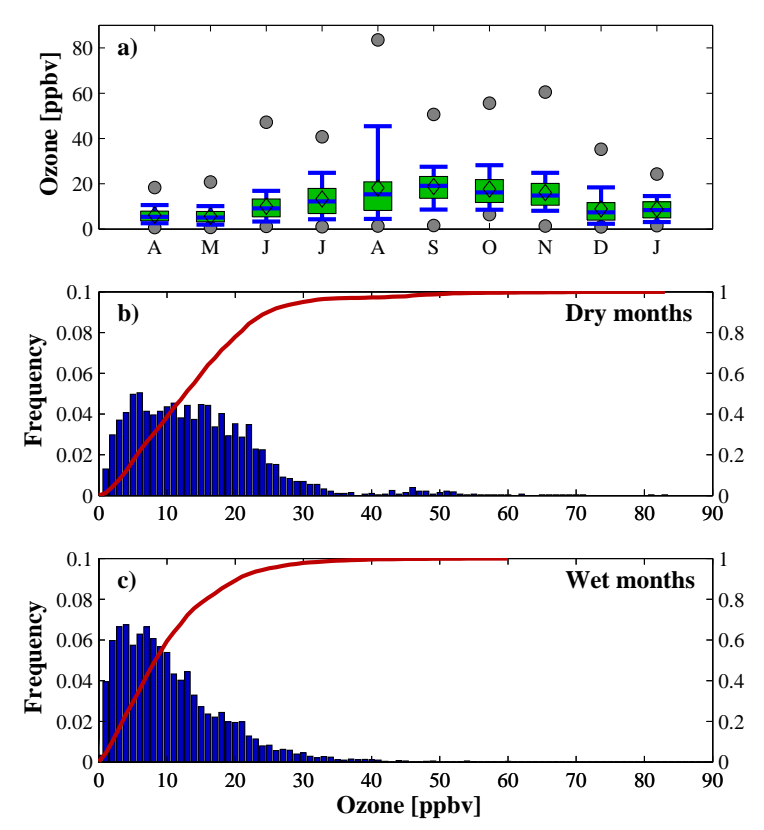

Figure 2: Ozone mixing ratios during April 2014 to January 2015: (a) Monthly ozone mixing ratios in ppbv during April 2014 to January 2015. Gray circles indicate minimum and maximum ozone mixing ratios. Black diamonds denote the mean, the boxplot shows lower-quartile, median and upper-quartile ozone mixing ratios. The whiskers indicate 10 th and 90 th percentiles. Frequency distributions of 30-minute averaged ozone mixing ratios during (b) dry months (Jun-Sept) and (c) wet months. The red lines (right axis) indicate the cumulative frequency distribution. burning in the Amazon (e.g., Kuhn et al., 2010; Artaxo et al., 2013). From the start of the wet months in October, median $\mathrm{O}_{3}$ mixing ratios declined while their maxima continued to rise until November. During December and January, $\mathrm{O}_{3}$ mixing ratios approached the values observed at the beginning of the field experiment. While monthly maximum $\mathrm{O}_{3}$ levels exceeded 35 ppbv during June to December, the overall frequency distribution indicated that these occurrences of elevated $\mathrm{O}_{3}$ were infrequent and represented less than $2.5 \%$ of the time and less than $5 \%$ during dry months. During the wet months, the median $\mathrm{O}_{3}$ mixing ratio remained close to $10 \mathrm{ppbv}$ with the exception of the months of October and November.

47 Ozone levels showed a clear diurnal variation in response to source and sink processes (Fig. 3). Ozone mixing ratios decreased during the night as a result of surface deposition and

$\mathrm{O}_{3}$ mixing ratios occurred in August and coincided with the maximum period of biomass 
chemical reactions with plant-emitted hydrocarbons that were mostly confined in the shallow and stable nocturnal boundary layer (Jardine et al., 2011; Bouvier-Brown et al., 2009). After sunrise, $\mathrm{O}_{3}$ mixing ratios increased due to photochemical formation and entrainment of $\mathrm{O}_{3^{-}}$ rich air into the boundary layer and to the forest. During the dry months, which included June to September, mean $\mathrm{O}_{3}$ mixing ratios were higher than during the wet months (20 versus $15 \mathrm{ppbv}$ ). Air masses arriving at the study site most often originated from clean areas where $\mathrm{NO}_{\mathrm{x}}$ remained in limited levels to contribute to $\mathrm{O}_{3}$ formation. The influence of clean air masses was evident in both averaged wet and dry month values that were much lower than $\mathrm{O}_{3}$ mixing ratios often recorded near populated areas. The lower $\mathrm{O}_{3}$ mixing ratios during the wet months (i.e., 10-15 ppbv) resulted in response to increased cloud cover that attenuated the actinic irradiance to drive photochemical processes. Similarly, during the wet months maximum diurnal $\mathrm{O}_{3}$ mixing ratios occurred earlier (plateauing 11:00-15:00 local time LT) than during the dry months (peak at 16:00 LT). During the dry months forest fires and biomass burning increased $\mathrm{NO}_{\mathrm{x}}$ concentrations and consequently contributed to enhanced $\mathrm{O}_{3}$ formation. Despite its remote location, the study site also experienced some episodes of high $\mathrm{O}_{3}$ levels during the wet months. Overall, such episodes were not uncommon and provided evidence of the increasingly important influences of human activities on the remote rainforest of the Amazon.

To investigate the potential influence of pollution plumes originating from Manaus and biomass burning associated with human settlements between Manaus and the study site on near-surface $\mathrm{O}_{3}$, daytime $(06: 00-18: 00 \mathrm{LT}) \mathrm{O}_{3}$ mixing ratios were segregated as a function of wind direction. During the dry months, elevated $\mathrm{O}_{3}$ mixing ratios were mostly associated with air masses coming from south-easterly sectors. For such wind directions, the mean $\mathrm{O}_{3}$ mixing ratio was $20 \mathrm{ppbv}$. Compared to the wet months, there were also more events during which $\mathrm{O}_{3}$ levels exceeded one standard deviation from the mean. Similarly, these events occurred mostly during winds from southerly to easterly directions and reached $\mathrm{O}_{3}$ levels exceeding 80 ppbv during one event $($ Fig. $3 \mathrm{c}+\mathrm{d})$. These high levels of $\mathrm{O}_{3}$ indicate the influence of pollutants originating from the City of Manaus to the south-southeast. 

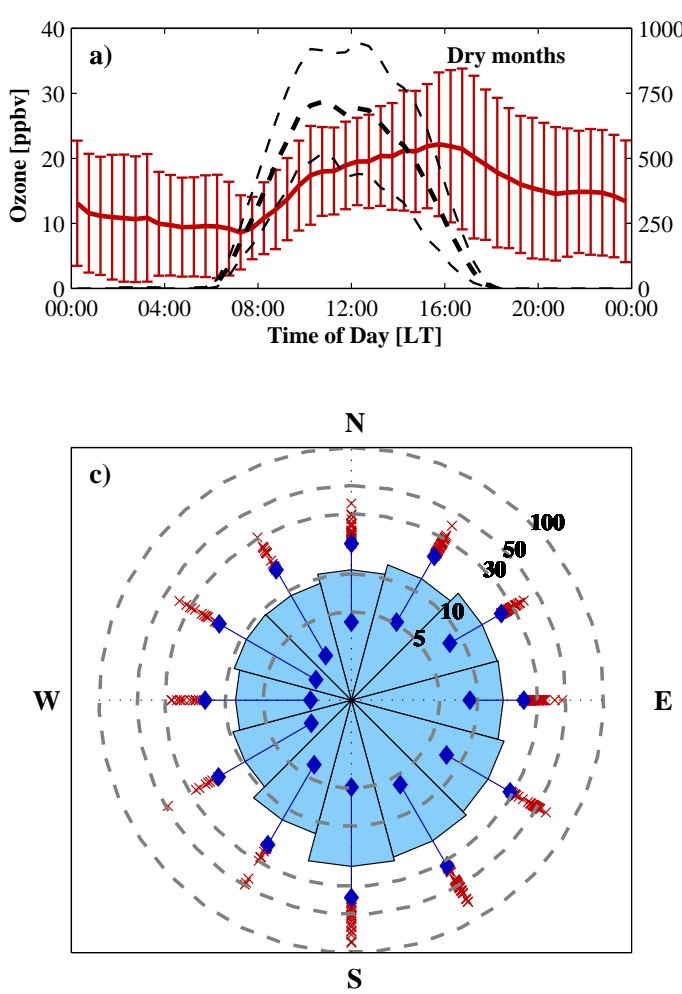
only reached 10-15 ppbv for all sectors.
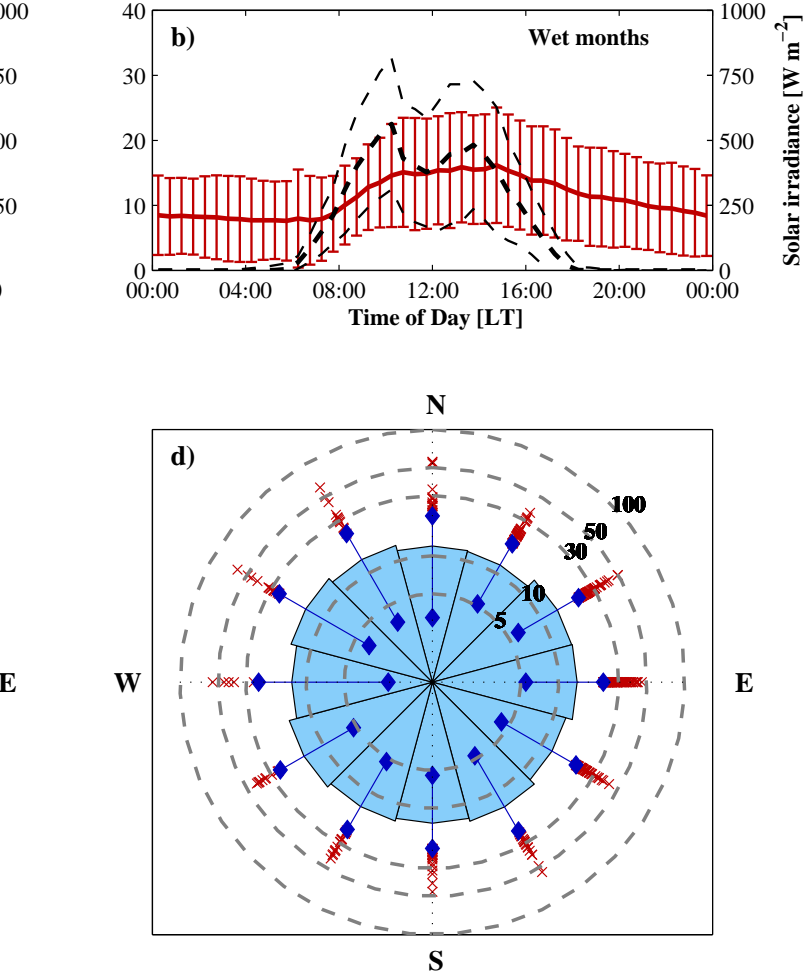

Figure 3: Average diel cycle of 30-minute mean ozone mixing ratios (red lines) as well as solar irradiance (black dashed lines) for (a) dry and (b) wet months. Standard deviation is indicated by bars (ozone) and thin dashed lines (solar irradiance). Subplots (c) and (d) display the mean daytime (06:00 LT - 18:00 LT) ozone mixing ratio based on wind direction. The standard deviation of daytime $\mathrm{O}_{3}$ mixing ratios for each sector is indicated with the blue diamonds and red crosses show values exceeding one standard deviation.

Increased human settlements along the highway from Manaus to the site, which is located to the east, could also contribute to the northward extension of forest fire plumes and additional pollution from human activities. In contrast, during the wet months mean $\mathrm{O}_{3}$ mixing ratio

\subsection{Case studies of ozone enhancements}

Due to its tropical location, the Amazon region experiences frequent occurrences of deep and moist convection. In addition to precipitation, storms are associated with downdrafts capable of generating substantial mass fluxes from the mid-troposphere to the surface. As air masses descend, $\mathrm{O}_{3}$ in the atmospheric boundary layer can abruptly increase (e.g., Betts 
et al., 2002; Grant et al., 2008) which can be detected by ground-level measurements. Two cases are provided to illustrate the unique signatures of $\mathrm{O}_{3}$ enhancements associated with convective storms of varying degrees of organization.

\subsubsection{Single storm event}

On 19 June 2014, an isolated MCS with a leading convective line and trailing stratiform precipitation passed through the region around 9:30 LT (Fig. $4 \mathrm{a}$ ). The fast moving system produced a precipitation peak of approximately $6 \mathrm{~mm}$ within a 30-minute interval, during which the convective line moved over the measurement site with weaker stratiform rain persisting for a few hours thereafter (Fig. 5). During the passage of the convective line, the surface $\mathrm{O}_{3}$ mixing ratio increased from 5 to more than $20 \mathrm{ppbv}$ with a corresponding decrease in $\theta_{e}$ of approximately $9 \mathrm{~K}$. Equivalent potential temperature is a conserved quantity in updrafts and downdrafts, indicating that the increase in $\mathrm{O}_{3}$ was caused by the downward transport of air from higher levels in the troposphere. This convective system occurred in the late morning hours and regionally enhanced the atmospheric boundary layer with $\mathrm{O}_{3}$ mixing ratios of $10 \mathrm{ppbv}$ for the rest of the day.

\subsubsection{Multi-storm day}

On 9 May 2014, convective activity was widespread across the region, but much less organized than on the 19 June case (Fig. 4 b-d). The site was subject to a sequence of precipitation events of increasing strength that were separated by short periods of dry conditions (Fig. 6). Each successive rain event (8:00, 11:30, and 13:30 LT) corresponded to an increase in the $\mathrm{O}_{3}$ mixing ratio and a decrease in $\theta_{e}$. Downdrafts associated with the first rain event at 8:00 LT caused an increase of $\mathrm{O}_{3}$ levels from 2 ppbv to more than 10 ppbv as well as a decrease in $\theta_{e}$ of approximately $4 \mathrm{~K}$. However, the first event produced less than $5 \mathrm{~mm}$ of rain and radar reflectivity was weak (Fig. 4). After the event, $\mathrm{O}_{3}$ mixing ratio decreased to $5 \mathrm{ppbv}$ and $\theta_{e}$ rose in response to strong solar irradiance and photochemical activity. Also, the atmospheric boundary layer depth likely increased. The second precipitation event at 11:30 LT increased surface $\mathrm{O}_{3}$ levels by 5 ppbv and a larger drop in $\theta_{e}$ than the first event. Rain rates were similar to the first rain event, but the duration of rainfall was longer and 

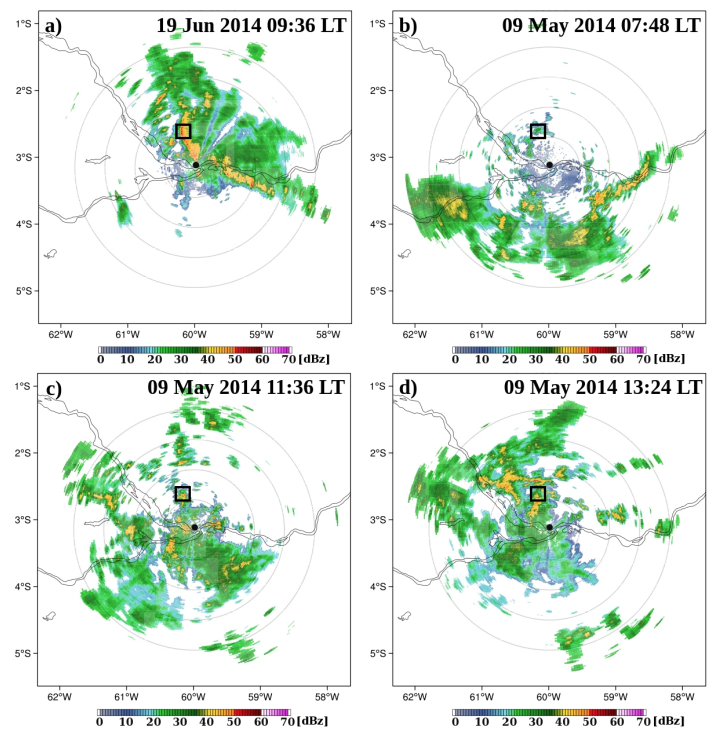

Figure 4: SIPAM S-band (10-cm wavelength) radar images at $0.9^{\circ}$ elevation angle for 19 June 2014 and 9 May 2014 at the time of the $\mathrm{O}_{3}$ enhancement events. The black squares indicate the location of the measurement site and the location of Manaus is indicated by the black circles. The storms travel from north-east to south-west.

the convective system appeared stronger according the radar reflectivity. The third event at 13:30 LT produced the largest rain rates, increased $\mathrm{O}_{3}$ levels further, and decreased $\theta_{e}$ approximately $10 \mathrm{~K}$ below the maximum. This convective system was also the strongest and most widespread of the three events. After 15:00 LT, stratiform rain set in and $\mathrm{O}_{3}$ mixing ratio decreased towards characteristic nighttime levels.

While each of the individual convective events on 9 May 2014 produced $\mathrm{O}_{3}$ increases in the order of $10 \mathrm{ppbv}$, in aggregate, their impacts on surface $\mathrm{O}_{3}$ were close to the single large increase observed on 19 June 2014. With the passing of each convective storm, vertical gradients and absolute $\mathrm{O}_{3}$ levels were reduced in the lower troposphere due to vertical redistribution. Therefore, the magnitude of ground-level $\mathrm{O}_{3}$ enhancements depended on the altitude where air parcels originated in the troposphere. The third and final event on 9 May 2014 (Fig. 6) provided an example of a stronger downdraft emanating from a higher altitude to further increase ground-level $\mathrm{O}_{3}$. 

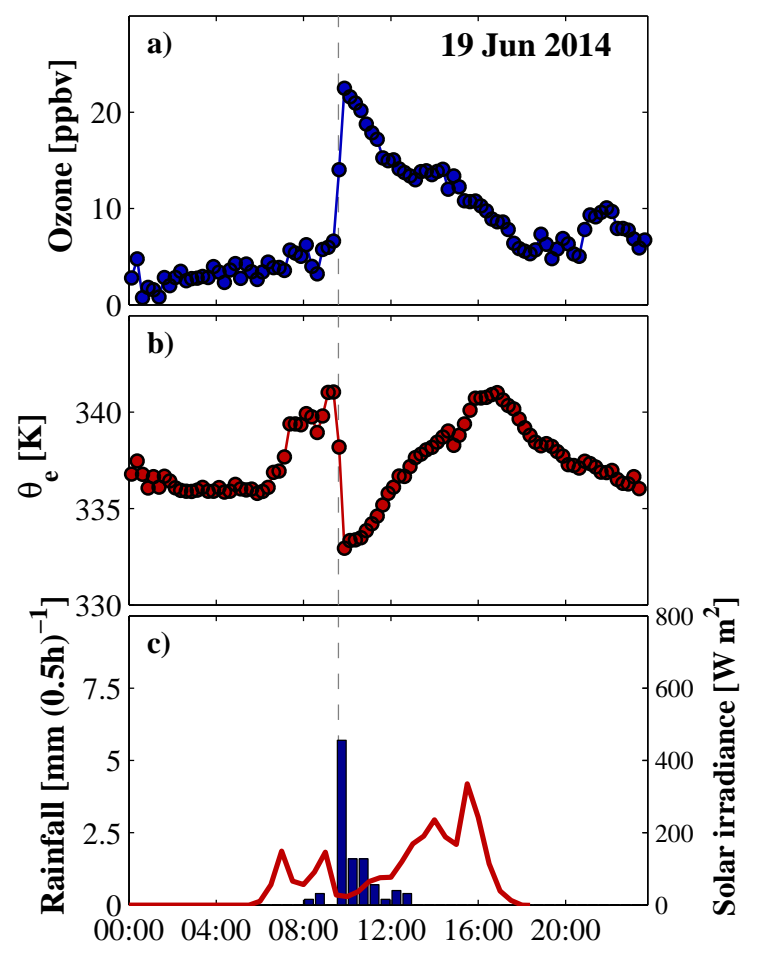

Time of Day [LT]

Figure 5: Case study of a single storm ozone enhancement on 19 June 2014: (a) Ozone mixing ratio [ppbv], (b) equivalent potential temperature $\left(\theta_{e},[\mathrm{~K}]\right)$, and (c) 30-minute accumulated precipitation $[\mathrm{mm}]$ and solar irradiance $\left[\mathrm{W} \mathrm{m}^{-2}\right]$ (red line). The dashed line indicates the times of the radar images in Figure 4. 

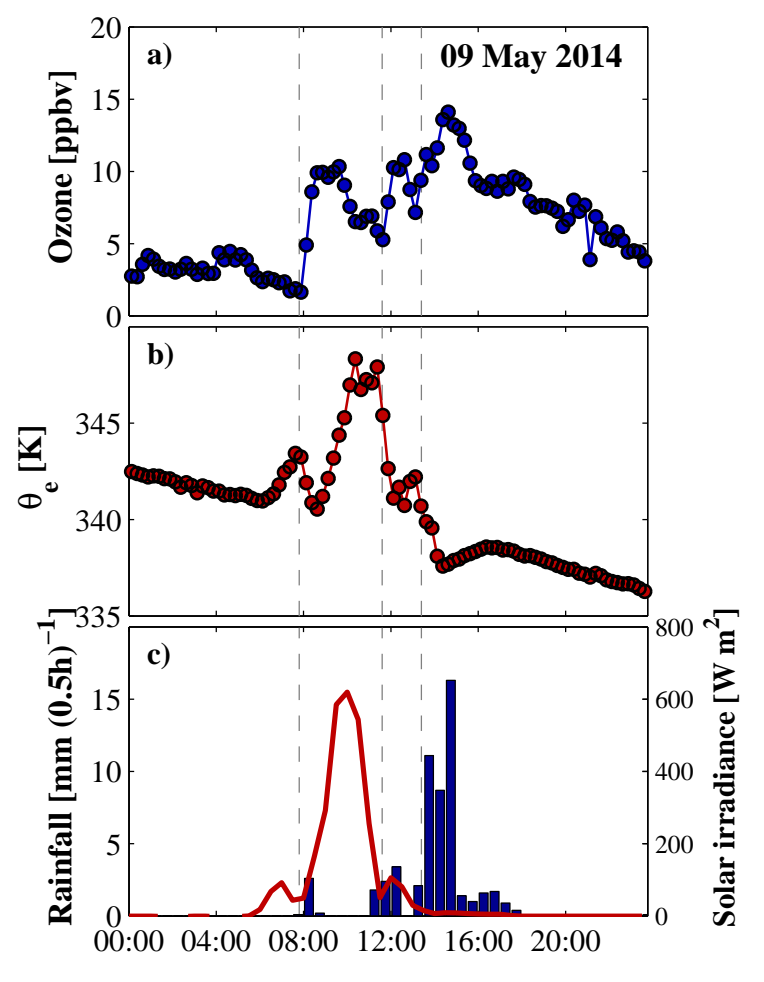

Time of Day [LT]

Figure 6: Case study of a multi-storm day on 9 May 2014.: (a) Ozone mixing ratio [ppbv], (b) equivalent potential temperature $\left(\theta_{e},[\mathrm{~K}]\right)$, and (c) 30-minute accumulated precipitation $[\mathrm{mm}]$ and solar irradiance $\left[\mathrm{W} \mathrm{m}^{-2}\right]$ (red line). The dashed lines indicate the times of the radar images in Figure 4. 

origin of $\mathrm{O}_{3}$-enriched air parcels transported down to the surface. For the case of 19 June

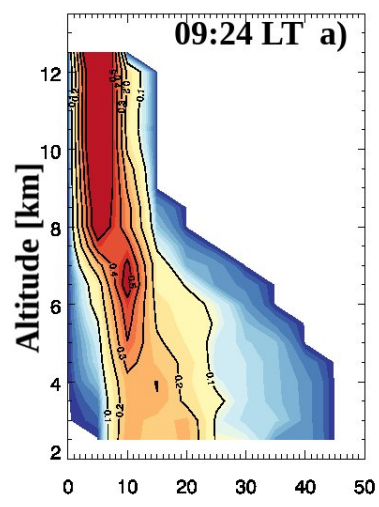

The magnitude of $\mathrm{O}_{3}$ enhancement depends on the strength of the downdraft and the
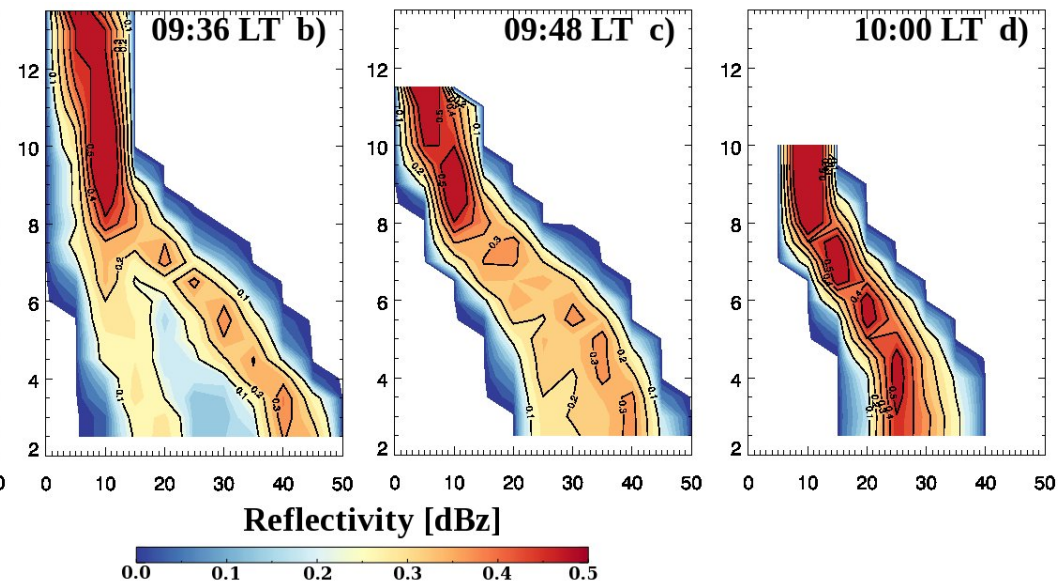

\subsubsection{Dynamics of ozone enhancement events}

Figure 7: Contoured frequency with altitude diagram (CFAD) of radar reflectivity observed by the SIPAM Sband radar located in Manaus for $22 \mathrm{~km} \times 22 \mathrm{~km}$ box centered above ZF2 during a 12-min period, on 19 June 2014. The contours represent the reflectivity occurrence at each height and a minimum count is applied so that the distribution at data sparse heights is not plotted.

2014, contoured-frequency-by-altitude diagrams (CFADs, see Yuter and Houze (1995)), show the storm's evolution between 9:24 and 10:00 LT, i.e., the period when the leading convective line passed over the site (Fig. 7). As the leading line passed over the site (09:24 LT), echo tops reached $12 \mathrm{~km}$ but radar reflectivity close to the surface was generally less than $30 \mathrm{dBz}$. Twelve minutes later (09:36 LT), echo tops were greater than $14 \mathrm{~km}$ and an arm of strong reflectivity starting around $7 \mathrm{~km}$ descended to the surface with a large portion of reflectivity values greater than $40 \mathrm{dBz}$. This feature persisted into the 09:48 LT volume scan and then disappeared by 10:00 LT as the leading line of the storm passed over the site and a more stratiform distribution of reflectivity (i.e., more tightly grouped contours at lower heights and reflectivity values) was subsequently observed. The descending arm of strong reflectivity was consistent with hydrometeors growing too large to be maintained by the convective updraft, creating a strong downdraft and heavy rain as they fall. The descending arm also coincided with the timing of the $\mathrm{O}_{3}$ enhancement and $\theta_{e}$ drop (Fig. 5). 

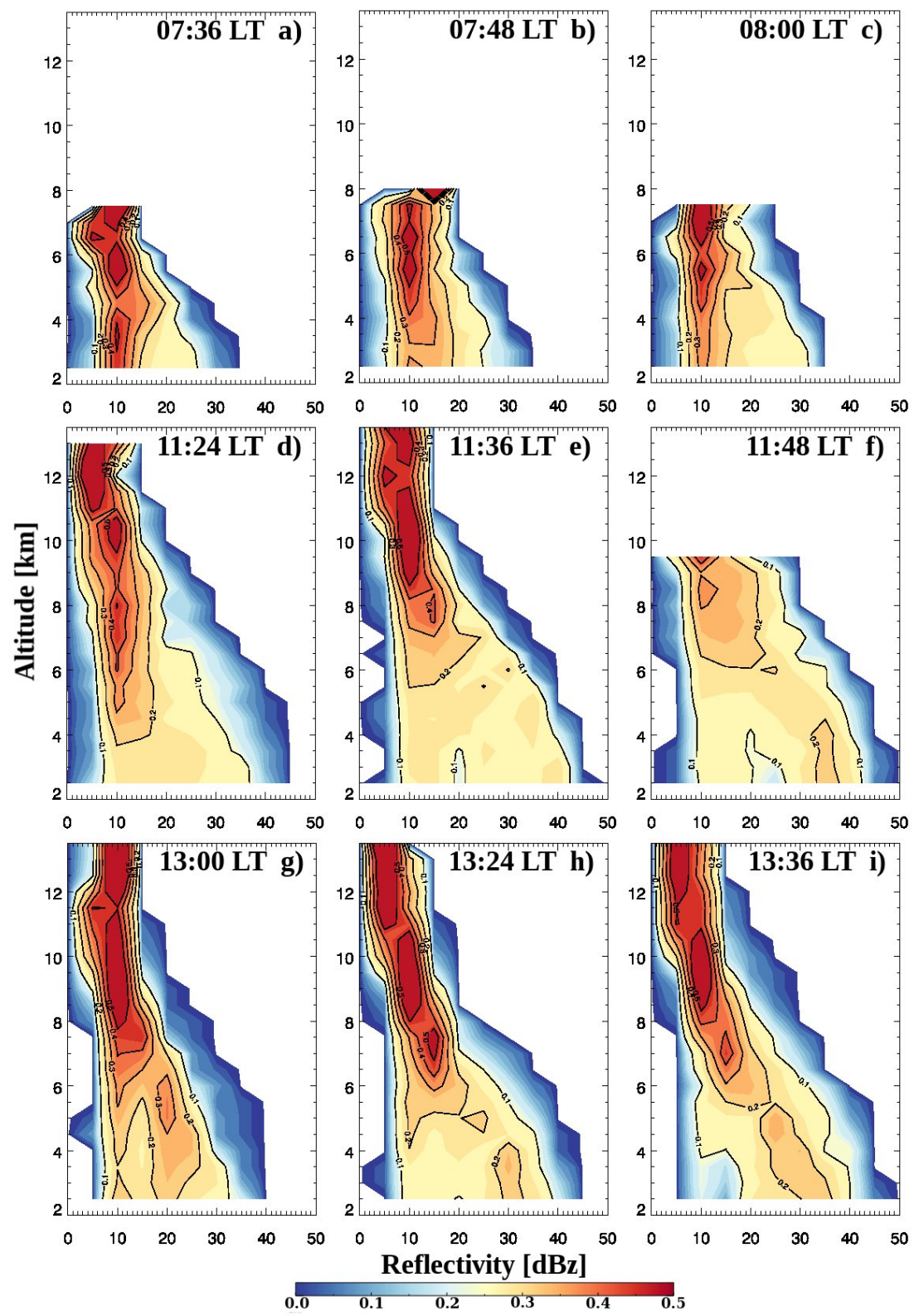

Figure 8: Contoured frequency with altitude diagram (CFAD) of radar reflectivity observed by the SIPAM S-band radar located in Manaus for $22 \mathrm{~km} \times 22 \mathrm{~km}$ box centered above ZF2 during a 12-min period, observing the storm system on 9 May 2014. The contours represent the reflectivity occurrence at each height and a minimum count is applied so that the distribution at data sparse heights is not plotted. 
Figure 8 shows the evolution of the three convective systems that passed over the site on 9 May 2014. The first event during 7:36 LT shows echo tops reaching only $8 \mathrm{~km}$ and surface reflectivity never exceeding $40 \mathrm{dBz}$, consistent with the low reflectivity values in Fig. 4 and low rainfall rate in Fig. 6. Similarly, no descending arm was evident, although there appeared to be a broadening of the reflectivity values below below $5 \mathrm{~km}$, the nominal $0{ }^{\circ} \mathrm{C}$ level in the tropics, which may be indicative of re-evaporation of precipitation and thus downdrafts. While this event appeared to be much weaker than the 19 June 2014 case, it still produced a strong $\mathrm{O}_{3}$ enhancement end $\theta_{e}$ reduction. Such an increase in $\mathrm{O}_{3}$ still appears plausible, based on the $\mathrm{O}_{3}$ mixing ratio profile from the AIRS-Instrument (Atmospheric InfraRed Sounder) on the Aqua satellite of $25 \mathrm{ppbv}$ at approximately $2000 \mathrm{~m}$ above ground level. The second event during 11:00 LT had higher echo tops (note that upper level radar data is missing during the 11:48 LT scan) and stronger surface reflectivity than during 8:00 LT. Once again, a weak and more shallow descending arm occurred as the convective system passed over the site. The third and strongest event of 9 May 2014 had consistently high echo tops and the most robust descending arm of the case studies that appeared to be linked to processes above the $0{ }^{\circ} \mathrm{C}$ level.

\subsubsection{Contrasting local and basin-scale convection}

The local effects from the passage of convective systems are associated with the largescale storm dynamics (Fig. 9). On 19 June 2014 (Fig. 9 a) a small, single MCS propagated quickly through the basin and over the site. Conversely, a large basin scale system was present on 9 May 2014 (Fig. 9 b), so that $\mathrm{O}_{3}$ enhancements likely affected a much larger area of the Amazon basin. However, despite the small spatial extent of individual storms, once occurring simultaneously throughout the basin, these storm types can also substantially and regionally increase ambient $\mathrm{O}_{3}$ levels in the atmospheric boundary layer.

In addition to the regional extent, large-scale dynamics also impact the photoxidation process discussed in section 3.4. Basin scale convection, produces persistent cloud cover, lowering the solar irradiance for extended periods of time, which can reduce actinic fluxes and the photoxidation of the BVOC. In contrast, local convection events are often followed 
by clear conditions shortly after the enhancement of $\mathrm{O}_{3}$ allowing for photoxidation to occur at high rates. Consequently, the type of convection as well as its spatial distribution within the Amazon basin, influence not only atmospheric chemistry within the atmospheric boundary layer, but can also constitute a mechanism of $\mathrm{O}_{3}$ downward transport and subsequent destruction on the basin scale.
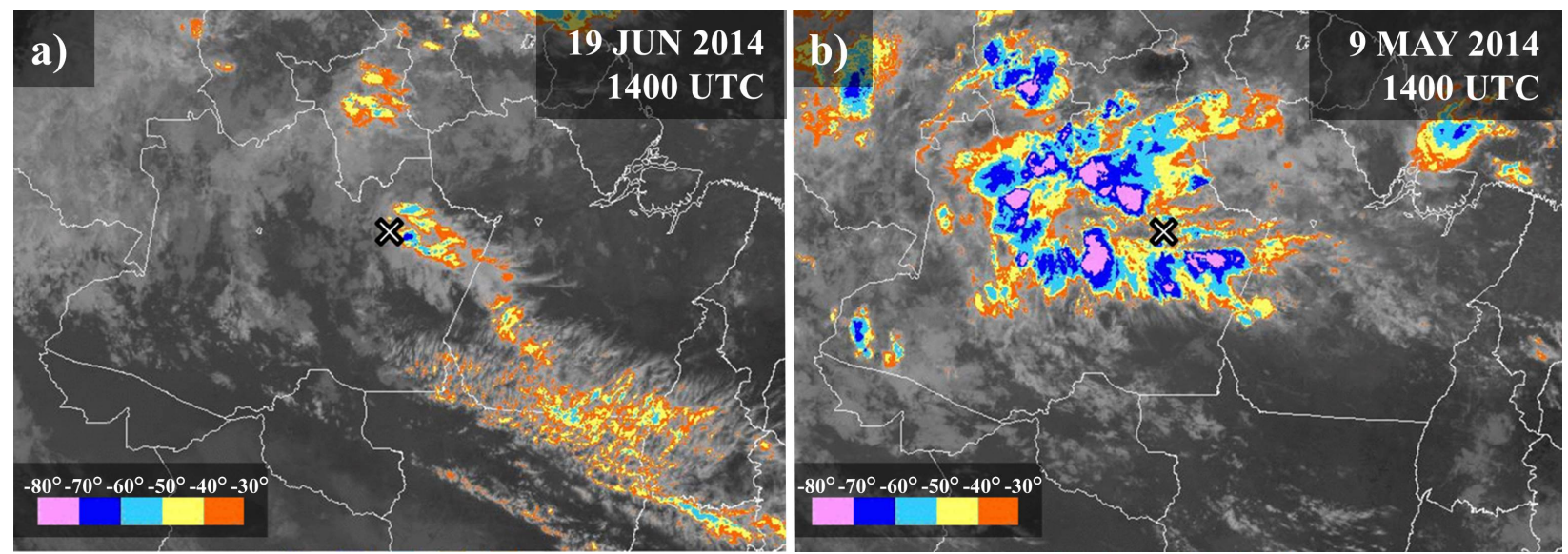

Figure 9: GOES-13 channel 4 images illustrating large-scale convection in the Amazon basin. 19 June 20141400 UTC (10:00 LT), (b) 9 May 20141400 UTC (10:00 LT). Overlaid colors show cloud top brightness temperatures below $-30{ }^{\circ} \mathrm{C}$. The cross indicates the location of the research site.

\subsection{Ozone enhancement event characterization}

In the tropical troposphere, $\mathrm{O}_{3}$ mixing ratios increase with altitude while $\theta_{e}$ decreases. During the wet season near Manaus, Kirchhoff et al. (1990) found an average $\mathrm{O}_{3}$ gradient of 6 ppbv km${ }^{-1}$ within $3-5 \mathrm{~km}$ of the troposphere. Such $\mathrm{O}_{3}$ vertical distribution resulted in a positive correlation between the strength of $\mathrm{O}_{3}$ enhancements and the magnitude of change in $\theta_{e}$ (Fig. 10). Between 5 and $10 \mathrm{~km}, \mathrm{O}_{3}$ remained almost invariant with height (Kirchhoff et al., 1990). However, upper tropospheric $\mathrm{O}_{3}$ mixing ratio for the same altitude exhibited large temporal variability (sometimes exceeding $25 \mathrm{ppbv}$ ) due to interactions between convection and vertical $\mathrm{O}_{3}$ distribution (e.g., Folkins et al., 2002; Folkins and Martin, 2005) and increased $\mathrm{O}_{3}$ formation from lightning-produced $\mathrm{NO}_{\mathrm{x}}$ (Goldenbaum and Dickerson, 1993; Thompson et al., 1997; Zhang et al., 2003). Those variations in $\mathrm{O}_{3}$ profiles and $\theta_{e}$ gradients 
were likely the reasons for the observed scatter in the relationship of $\mathrm{O}_{3}$ and $\theta_{e}$ changes. Furthermore, they may also help to explain the different magnitude of $\mathrm{O}_{3}$ enhancements associated with single (e.g., 19 June) versus multiple storm events (e.g., 9 May).

The magnitude of $\mathrm{O}_{3}$ enhancements depended on the time of day when storms occurred. During 2014, more daytime than nighttime storm events occurred (Fig. 10). This observation is in agreement with the preferential timing of convective precipitation during late morning and early afternoon hours. The nighttime response of $\mathrm{O}_{3}$ to changes in $\theta_{e}$ appeared to be stronger than during the daytime, which could be in response to temporal $\mathrm{O}_{3}$ variability in the atmospheric boundary layer. After sunset, $\mathrm{O}_{3}$ in the stable boundary layer becomes mostly depleted due to dry deposition and chemical reactions while $\mathrm{O}_{3}$ above the boundary layer does not exhibit much diurnal variability (Kirchhoff et al., 1990). As a result, large $\mathrm{O}_{3}$ gradients likely developed between air in the stable boundary layer and the mid-troposphere, where the downdrafts originated. Conversely, during the daytime the net effect of $\mathrm{O}_{3}$-rich downdrafts was less pronounced as photochemical processes increased $\mathrm{O}_{3}$ levels in the boundary layer, thereby likely yielding reduced $\mathrm{O}_{3}$ gradients between the convective boundary layer and the mid-troposphere. The convective boundary layer, whose depths typically reach between 800 and $1200 \mathrm{~m}$, remained well mixed with respect to $\mathrm{O}_{3}$. While there seemed to be little difference in the strength of $\mathrm{O}_{3}$ enhancements between days with the passage of single or multiple convective systems, strong enhancements $\left(\Delta \mathrm{O}_{3}>15 \mathrm{ppb}\right)$ for days with multiple events were rare. This finding seems to be counter-intuitive, as more organized and basin scale convection was associated with much stronger precipitation as well as downdraft strengths. However, the repeated passage of convective systems caused increased vertical mixing of mid-tropospheric air towards and into the boundary layer such that mixing ratio gradients between near surface $\mathrm{O}_{3}$ and upper levels were reduced. It thus diminished the overall magnitude of individual events associated with the more organized and basin scale convection. Storm downdrafts increased $\mathrm{O}_{3}$ between 5 and 25 ppbv (Fig. $10 \mathrm{~b}$ ).

The length of time when the atmospheric boundary layer remains enriched with $\mathrm{O}_{3}$ is needed to investigate whether $\mathrm{O}_{3}$ enhancements significantly influence regional air chem- 

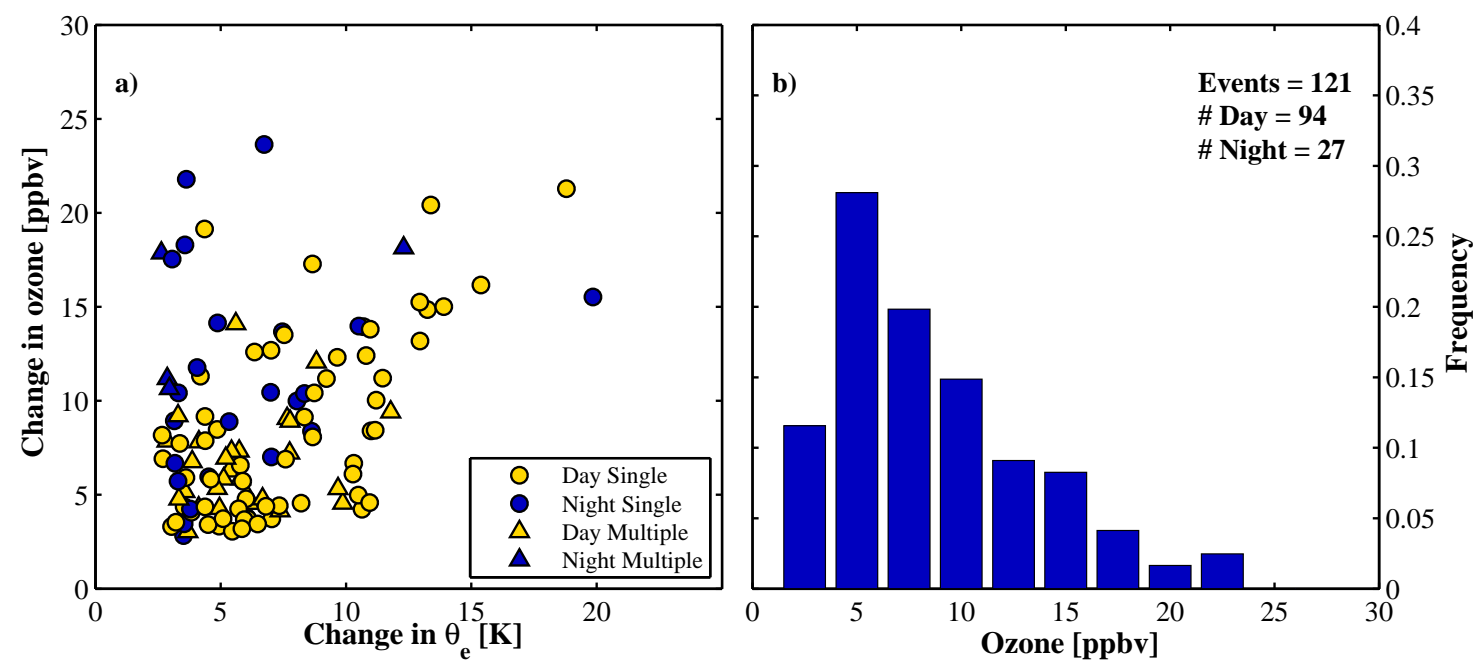

Figure 10: Aggregated changes in ozone during enhancement events from April 2014 to January 2015: (a) Change in ozone with respect to change in equivalent potential temperature for daytime (yellow) and nighttime (blue) cases as well as single (circle) and multiple events (triangle); (b) Frequency distribution of ozone events.

istry. Prior to the event onset, daytime $\mathrm{O}_{3}$ mixing ratios decreased while $\theta_{e}$ did not change significantly (as illustrated by an extreme case in Fig. $11 \mathrm{a}+\mathrm{b}$ ) in response to atmospheric boundary layer air swiftly moving with storm updrafts. Stronger winds and updrafts transported warm, moist, and $\mathrm{O}_{3}$-depleted in-canopy air to sensor level above the canopy, thus increasing $\theta_{e}$ and decreasing $\mathrm{O}_{3}$ for short periods of time. During the nighttime, there was no corresponding increases in $\theta_{e}$ due to reduced temperature. This can be explained by the difference of in-canopy gradients of $\mathrm{O}_{3}$ mixing ratio and temperature as well as moisture, which dominate the observed changes in $\theta_{e}$.

The median nighttime change in $\theta_{e}$ was smaller than the daytime change (approximately -3 and $-5 \mathrm{~K}$ ), as nighttime values of $\theta_{e}$ are generally smaller and have less temporal variation. Shortly before the start of the event, $\mathrm{O}_{3}$ mixing ratios decreased during daytime conditions, while $\theta_{e}$ remained virtually unchanged. This was due to the dynamics of the passing storms. While chemical reactions and dry deposition cause noticeable $\mathrm{O}_{3}$-gradients within the canopy, the in-canopy air was much better mixed with respect to temperature and humidity. Subsequently, $\mathrm{O}_{3}$ mixing ratios and $\theta_{e}$ started to change due to storm down- 
drafts. As storms propagated, downdrafts dominated the transport process. On average, nighttime median changes of $\mathrm{O}_{3}$ were greater than daytime changes with approximately 7.5 and 4 ppbv, respectively. Maximum $\mathrm{O}_{3}$ levels were reached after circa $1 \mathrm{~h}$ and 50 minutes for nighttime and daytime events followed by a gradual decline of $\mathrm{O}_{3}$ mixing ratios during daytime conditions, which was likely due to chemical reactions with BVOCs. For nighttime events, increases in $\mathrm{O}_{3}$ persisted for two hours.

The increase of the median $\mathrm{O}_{3}$ levels for all events exceeded 5 ppbv, while $25 \%$ of all events exceeded 9 ppbv. Given the range of $\mathrm{O}_{3}$ changes between 1 and $10 \mathrm{ppbv}$ and typical ambient $\mathrm{O}_{3}$ mixing ratios between 5 and $25 \mathrm{ppb}$, the impact of these events on air chemical processes cannot be neglected, especially as their influence on $\mathrm{O}_{3}$ levels was still detectable for at least two hours after the onset of the event and thus had the potential to affect chemical reactions for extended periods of time. Similarly, Sigler et al. (2002) have shown that there is a difference in the diurnal cycle of $\mathrm{O}_{3}$ mixing ratios for days with and without the passage of convective systems.
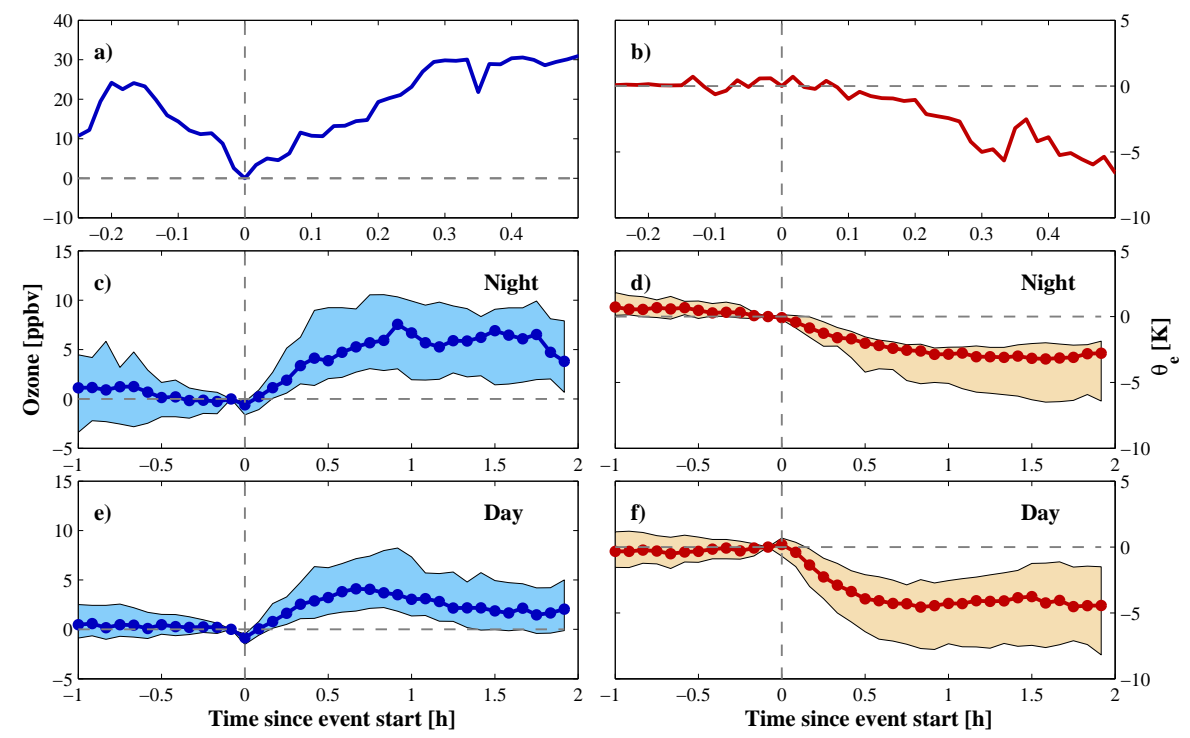

Figure 11: Changes in ozone and equivalent potential temperature $\left(\theta_{e}\right)$ during ozone enhancement events: 1-minute averages for (a) ozone and (b) $\theta_{e}$ on 22 Aug 2014, 20:55 LT; (c+d) median change for nighttime events; and $(\mathrm{e}+\mathrm{f})$ daytime events from 5 -minute averaged data. The colored patches give the interquartile range of events. 


\subsection{Influences on atmospheric chemistry}

The rainforest emits numerous hydrocarbon species including isoprene, monoterpenes (e.g., $\alpha$-pinene), sesquiterpenes (e.g., caryophyllene), and oxygenated compounds (e.g., methanol). At the study site, the most abundant and important hydrocarbons measured above the rainforest included isoprene and monoterpenes whose daily maximum mixing ratios reached 15 and $2 \mathrm{ppbv}$, respectively (Fuentes et al., in review). Isoprene and monoterpenes react with $\mathrm{O}_{3}$ and the reactions provide an important source of $\mathrm{HO}$ (Paulson and Orlando, 1996), which can subsequently enhance the oxidation of rainforest-emitted hydrocarbons. To determine the magnitude of $\mathrm{HO}$ formation from reactions of $\mathrm{O}_{3}$ with BVOCs, the $\mathrm{HO}$ formation rates were computed following equation 9.

$$
\frac{\partial[\mathrm{OH}]}{\partial \mathrm{t}}=\sum_{i}^{N}[\mathrm{BVOC}]_{i} K_{i}\left[\mathrm{O}_{3}\right] \mathrm{Yield}_{i}
$$

$\mathrm{N}$ denotes the total number of identified hydrocarbons above the rainforest, $[\mathrm{BVOC}]_{i}$ represents the concentration (molecules $\mathrm{cm}^{-3}$ ) of speciated hydrocarbon, $i$ (i.e., isoprene, $\alpha$-pinene, etc.), $\mathrm{K}_{i}$ is the reaction rate coefficient $\left(\mathrm{cm}^{3}\right.$ molecules $\left.{ }^{-1} \mathrm{~s}^{-1}\right)$ of $[\mathrm{BVOC}]_{i}$ with $\mathrm{O}_{3},\left[\mathrm{O}_{3}\right]$ is the $\mathrm{O}_{3}$ concentration (molecules $\mathrm{cm}^{-3}$ ), and $\mathrm{Yield}_{i}$ is the $\mathrm{HO}$ yield (unitless) from the reaction of $[\mathrm{BVOC}]_{i}$ with $\mathrm{O}_{3}$. The speciated monoterpenes measured above the forest (Jardine et al., 2015), associated $\mathrm{O}_{3}$ reactivities, and $\mathrm{HO}$ yields are included in Table 1. Following storms, isoprene and monoterpene mixing ratios exhibited an interquartile ranges of 1.5 to 3.0 and 0.3 to $0.7 \mathrm{ppbv}$.

Ozone enhancements due to storms resulted in substantial HO production rates. For example, an $\mathrm{O}_{3}$ enhancement from 5 to $30 \mathrm{ppbv}$ would increase $\mathrm{HO}$ production rates from $0.15-0.29 \times 10^{5}$ free radicals $\mathrm{cm}^{-3} \mathrm{~s}^{-1}$ to $0.88-1.75 \times 10^{5}$ free radicals $\mathrm{cm}^{-3} \mathrm{~s}^{-1}$ for the range of 1.5 to 3.0 pbbv of isoprene (Fig. $12 \mathrm{a}$ ). Likewise, HO formation rates increase from 0.18 $0.42 \times 10^{6}$ free radicals $\mathrm{cm}^{-3} \mathrm{~s}^{-1}$ to $1.08-2.53 \times 10^{5}$ free radicals $\mathrm{cm}^{-3} \mathrm{~s}^{-1}$, for a monoterpene range of 0.3 to $0.7 \mathrm{ppbv}$ (Fig. $12 \mathrm{~b}$ ).

These HO formation rates closely compare with estimates obtained for regions supporting intense summertime photochemical activity dominated by enhanced $\mathrm{NO}_{\mathrm{X}}$ and BVOC 
levels (Fuentes et al., 2007). Ozone enhancements also substantially reduced the lifetimes of isoprene and monoterpenes, defined as $\tau_{\text {Isop }}=\left(K_{\text {Isop }}\left[\mathrm{O}_{3}\right]\right)^{-1}$ and $\tau_{\text {Mono }}=\sum_{i}^{N}\left(K_{i}\left[\mathrm{O}_{3}\right]\right)^{-1}$. For instance, an $\mathrm{O}_{3}$ enhancements from 10 to $40 \mathrm{ppbv}$ caused $\tau_{\text {Isop }}$ to decline from 90 to 20 hours whereas $\tau_{\text {Mono }}$ decreased from 40 to 8 hours (Fig. 12c). The reductions in isoprene and monoterpene lifetimes (Fig. 12) do not include the sinks resulting from reactions with HO. Nonetheless, in environments such as the rainforest, where BVOCs exist in elevated concentrations (e.g., Jardine et al., 2015), $\mathrm{O}_{3}$ initiates a chain of chemical reactions involving BVOCs that in the process generate not only abundant amounts of $\mathrm{HO}$ but also reaction products which serve as precursors of secondary organic aerosols. 

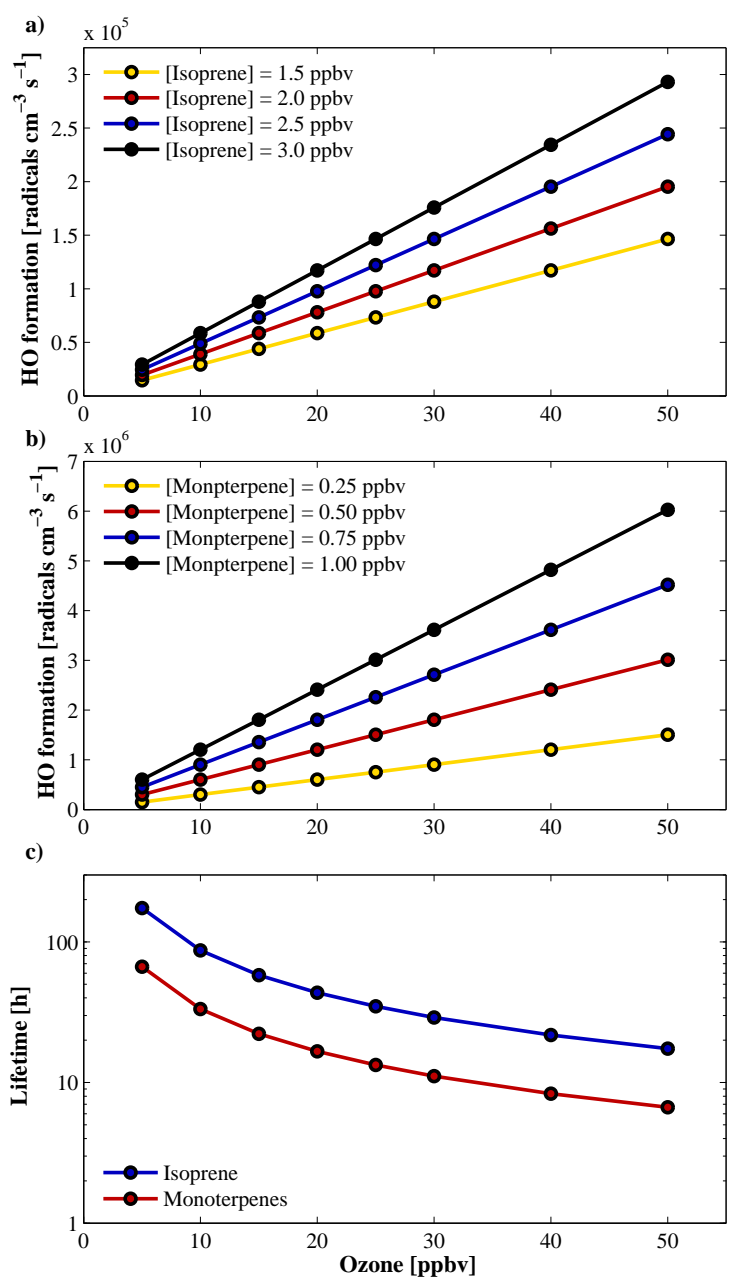

Figure 12: Hydroxyl radical formation rates from the oxidization of (a) isoprene with ozone, (b) monoterpenes with ozone and (c) isoprene and monoterpene lifetimes as a function of ambient ozone mixing ratios. 


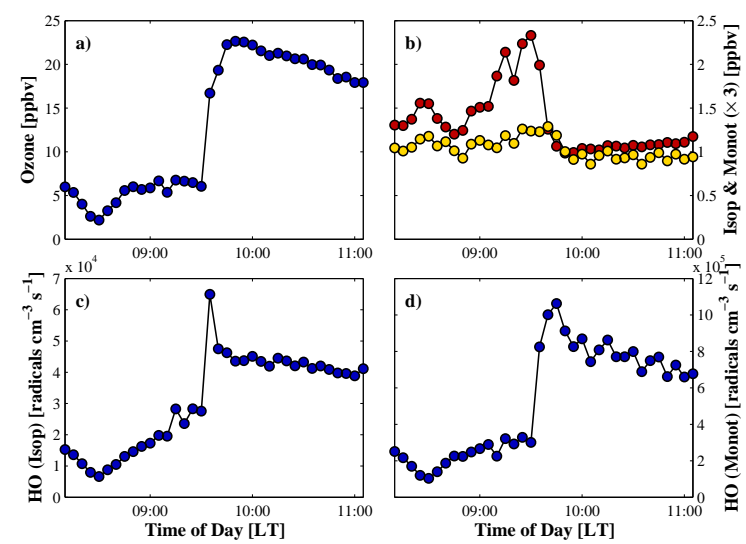

Figure 13: Hydroxyl radical formation rates [radicals cm $\mathrm{cm}^{-3} \mathrm{~s}^{-1}$ ] during the single storm day (19 June 2014) in response to (a) ozone, (b) isoprene (red) and monoterpene (yellow) mixing ratios for oxidation of (c) isoprene and (d) monoterpenes. Monoterpene mixing ratios were multiplied by a factor of 3 for scale reasons. 
The passage of the storm on 19 June 2014 provides one example of the impact of $\mathrm{O}_{3}$ enhancement events on $\mathrm{HO}$ formation rates (Fig. 13). The increase in $\mathrm{O}_{3}$ of this event compensated for the decrease in isoprene and monoterpene levels, leading to increased HO formation rates during and after the storm. The increase $\mathrm{HO}$ formation rates coincided with a period of low actinic irradiance (as deduced from incoming solar irradiance).

Table 1: Ozone reactivities and HO yields for the speciated hydrocarbons found over the rainforest at the Cuieiras Biological Reserve during the wet months of 2014.

\begin{tabular}{llll}
\hline Chemical species & $\begin{array}{l}\text { Ozone reactivities } \\
{\left[\mathrm{cm}^{3} \text { molecules }^{-1} \mathrm{~s}^{-1}\right]^{\psi}}\end{array}$ & $\begin{array}{l}\text { HO yield } \\
{[\text { Unitless }]}\end{array}$ & \\
\hline \hline Isoprene & $1.30 \times 10^{-17}$ & 0.25 & (Paulson et al., 1998) \\
$\alpha$-pinene & $2.35 \times 10^{-17}$ & 0.83 & (Rickard et al., 1999) \\
$\beta$-pinene & $3.79 \times 10^{-17}$ & 0.35 & (Atkinson et al., 1992) \\
3-Carene & $2.35 \times 10^{-17}$ & 0.86 & (Aschmann et al., 2002) \\
Camphene & $9.00 \times 10^{-19}$ & 0.18 & (Atkinson et al., 1992) \\
Limonene & $2.50 \times 10^{-16}$ & 0.67 & (Aschmann et al., 2002) \\
Sabinene & $2.50 \times 10^{-16}$ & 0.33 & (Aschmann et al., 2002) \\
$\beta$-Myrcene & $4.70 \times 10^{-16}$ & 0.63 & (Aschmann et al., 2002) \\
$\alpha$-Ocimeme & $5.40 \times 10^{-16}$ & 0.55 & (Aschmann et al., 2002) \\
Terpinolene & $1.90 \times 10^{-15}$ & 0.74 & (Aschmann et al., 2002) \\
$\gamma$-Terpinene & $1.40 \times 10^{-16}$ & 0.81 & (Aschmann et al., 2002) \\
\hline
\end{tabular}

\%: Kinetics data are from (Atkinson et al., 2006).

\section{Summary and conclusions}

Convective storms are ubiquitous features that redistribute $\mathrm{O}_{3}$ in the tropical troposphere. In the Amazon region, convective downdrafts frequently transport air parcels to the surface that provide distinct signatures of $\mathrm{O}_{3}$ enhancements. Isolated storms generate 
single and abrupt $\mathrm{O}_{3}$ enhancements whereas convectively active days produce multiple and successive $\mathrm{O}_{3}$ increases. Depending on the strength of storm downdrafts and height from which air parcels emanate, $\mathrm{O}_{3}$ enhancements can reach as much as 30 ppbv. Such $\mathrm{O}_{3}$ enhancements are associated with rapid declines in $\theta_{e}$, ranging from 3 to $20 \mathrm{~K}$. Radar and $\theta_{e}$ data indicate that air parcels, which transport $\mathrm{O}_{3}$-rich air to the surface originate $2-7 \mathrm{~km}$ above the ground. While there are comparatively few $\mathrm{O}_{3}$ enhancement events during the nighttime, these events typically lead to greater $\mathrm{O}_{3}$ enhancements due to the $\mathrm{O}_{3}$ difference in the atmospheric surface layer and the free troposphere. Following convective storms, the atmospheric boundary layer can be enriched with $\mathrm{O}_{3}$ for periods lasting $>2$ hours, the first hour experiencing the greatest $\mathrm{O}_{3}$ enhancements. Due to their long lifetime and large size, basin scale systems increase cloud cover which reduces photochemical processes for extended times, whereas local systems are often followed by clear conditions and thus enhance photochemistry.

Convective storms sufficiently enhance the atmospheric boundary layer with $\mathrm{O}_{3}$ to initiate a chain of chemical reactions involving rainforest-emitted hydrocarbons. Reactions of $\mathrm{O}_{3}$ with hydrocarbons generate substantial amounts of $\mathrm{HO}$ which additionally contribute to the oxidation of hydrocarbons. In response to reactions of $\mathrm{O}_{3}$ with prevailing monoterpenes

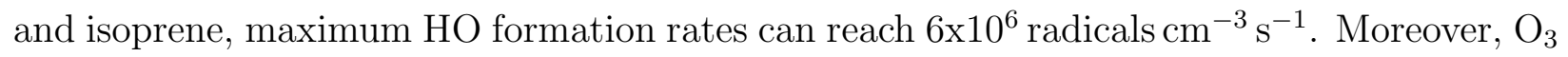
enhancements can substantially reduce the lifetimes of isoprene and monoterpenes. Therefore, one key conclusion derived from this investigation is that, in the Amazon rainforest, convective systems can transport sufficient $\mathrm{O}_{3}$ to the canopy to drive oxidation of rainforestemitted hydrocarbons. It is hypothesized that $\mathrm{O}_{3}$ enhancement events can thus accelerate the production of SOAs which can activate into cloud condensation nuclei, and thereby might influence cloud formation.

\section{Acknowledgments}

The U.S. Department of Energy Office of Biological and Environmental Research's Climate and Environmental Sciences Division supported the field studies as part of the GoAmazon 2014/5 project (grant SC0011075). Fundação de Amparo à Pesquisa do Estado de 
São Paulo (FAPESP) and Fundação de Amparo à Pesquisa do Estado do Amazonas (FAPEAM) funded the Brazilian component of the field studies. We acknowledge the support from the Central Office of the Large Scale Biosphere Atmosphere Experiment in Amazonia (LBA), the Instituto Nacional de Pesquisas da Amazonia (INPA), and the Universidade do Estado do Amazonia (UEA). The work was conducted under 001030/2012-4 of the Brazilian National Council for Scientific and Technological Development (CNPq). We acknowledge logistical support from the ARM Climate Research Facility. Juliane Mercer and Brazilian students Raoni Aquino Silva de Santana, Debora Tanya, and Francisco assisted with the field studies. Satellite images are courtesy of Instituto Nacional de Pesiquisas Espacias (INPA) Divisão de Satelites e Sistémas Ambientais. Radar data are courtesy of SIPAM and Hannah Upton and Aaron Funk of Texas A\&M University. The SIPAM radar analysis and imagery were completed with support from DOE ASR grant DE-SC0008561 and the Texas A\&M University-CAPES Collaborative Research Grant Program. LATM acknowledges the support of FAPESP (Grant 2009/15235-8). PCS acknowledges the support from the Alexander von Humboldt Foundation.

\section{References}

Artaxo, P., Rizzo, L. V., Brito, J. F., Barbosa, H. M. J., Arana, A., Sena, E. T., Cirino, G. G., Bastos, W., Martin, S. T., Andreae, M. O., 2013. Atmospheric aerosols in Amazonia and land use change: from natural biogenic to biomass burning conditions. Faraday Discussions $165(0), 203-235$.

Aschmann, S. M., Arey, J., Atkinson, R., 2002. OH radical formation from the gas-phase reactions of O3 with a series of terpenes. Atmospheric Environment 36 (27), 4347-4355.

Atkinson, R., Aschmann, S. M., Arey, J., Shorees, B., 1992. Formation of OH radicals in the gas phase reactions of $\mathrm{O}_{3}$ with a series of terpenes. Journal of Geophysical Research 97 (D5), 6065-6073.

Atkinson, R., Baulch, D. L., Cox, R. A., Crowley, J. N., Hampson, R. F., Hynes, R. G., 
Jenkin, M. E., Rossi, M. J., Troe, J., IUPAC Subcommittee, 2006. Evaluated kinetic and photochemical data for atmospheric chemistry: Volume II - gas phase reactions of organic species. Atmospheric Chemistry and Physics 6 (11), 3625-4055.

Bela, M. M., Longo, K. M., Freitas, S. R., Moreira, D. S., Beck, V., Wofsy, S. C., Gerbig, C., Wiedemann, K., Andreae, M. O., Artaxo, P., 2015. Ozone production and transport over the Amazon Basin during the dry-to-wet and wet-to-dry transition seasons. Atmospheric Chemistry and Physics 15, 757-782.

Bertram, T. H., Perring, A. E., Wooldridge, P. J., Crounse, J. D., Kwan, A. J., Wennberg, P. O., Scheuer, E., Dibb, J., Avery, M., Sachse, G., Vay, S. A., Crawford, J. H., McNaughton, C. S., Clarke, A., Pickering, K. E., Fuelberg, H., Huey, G., Blake, D. R., Singh, H. B., Hall, S. R., Shetter, R. E., Fried, A., Heikes, B. G., Cohen, R. C., 2007. Direct measurements of the convective recycling of the upper troposphere. Science 315 (5813), $816-820$.

Betts, A. K., Gatti, L. V., Cordova, A. M., Silva Dias, M. A. F., Fuentes, J. D., 2002. Transport of ozone to the surface by convective downdrafts at night. Journal of Geophysical Research 107 (D20), 8046.

Bouvier-Brown, N. C., Goldstein, A. H., Gilman, J. B., Kuster, W. C., de Gouw, J. A., 2009. In-situ ambient quantification of monoterpenes, sesquiterpenes, and related oxygenated compounds during BEARPEX 2007: Implications for gas- and particle-phase chemistry. Atmospheric Chemistry and Physics 9, 5505-5518.

Folkins, I., Braun, C., Thompson, A. M., Witte, J., 2002. Tropical ozone as an indicator of deep convection. Journal of Geophysical Research 107 (D13), 4184.

Folkins, I., Martin, R. V., 2005. The vertical structure of tropical convection and its impact on the budgets of water vapor and ozone. Journal of the Atmospheric Sciences 62 (5), $1560-1573$. 
Fuentes, J. D., Wang, D., Bowling, D. R., Potosnak, M., Monson, R. K., Goliff, W. S., Stockwell, W. R., 2007. Biogenic hydrocarbon chemistry within and above a mixed deciduous forest. Journal of Atmospheric Chemistry 56 (2), 165-185.

Fuentes, J. D., Chamecki, M., Nascimento dos Santos, R. M., von Randow, C., Stoy, P. C., Katul, G. G., Fitzjarrald, D. R., Manzi, A. O., Gerken, T., Trowbridge, A., Freire, L. S., Ruiz-Plancarte, J., Furtunato Maia, J. M., Tóta, J., Dias, N. L., Fisch, G., Schumacher, C., Acevedo, O. C., Mercer, J. R., Linking meteorology, turbulence, and air chemistry in the Amazon rainforest during the GoAmazon project. Bulletin of the American Meteorological Society, in review.

Garstang, M., Scala, J., Greco, S., Harriss, R., Beck, S., Browell, E., Sachse, G., Gregory, G., Hill, G., Simpson, J., Tao, W.-K., Torres, A., 1988. Trace gas exchanges and convective transports over the Amazonian rain forest. Journal of Geophysical Research 93 (D2), $1528-1550$.

Goldenbaum, G. C., Dickerson, R. R., 1993. Nitric oxide production by lightning discharges. Journal of Geophysical Research 98 (D10), 18333-18338.

Grant, D. D., Fuentes, J. D., DeLonge, M. S., Chan, S., Joseph, E., Kucera, P., Ndiaye, S. A., Gaye, A. T., 2008. Ozone transport by mesoscale convective storms in western Senegal. Atmospheric Environment 42 (30), 7104-7114.

Greco, S., Swap, R., Garstang, M., Ulanski, S., Shipham, M., Harriss, R. C., Talbot, R., Andreae, M. O., Artaxo, P., 1990. Rainfall and surface kinematic conditions over central Amazonia during ABLE 2B. Journal of Geophysical Research 95 (D10), 17001-17014.

Gregory, G. L., Browell, E. V., Warren, L. S., 1988. Boundary layer ozone: An airborne survey above the Amazon Basin. Journal of Geophysical Research 93 (D2), 1452-1468.

Gu, L., Baldocchi, D., Verma, S. B., Black, T.A., Vesala, T., Falge, E. M., Dowty, P. R., 2002. Advantages of diffuse radiation for terrestrial ecosystem productivity. Journal of Geophysical Research 107 (D6), 4050. 
Hu, X.-M., Fuentes, J. D., Zhang, F., 2010. Downward transport and modification of tropospheric ozone through moist convection. Journal of Atmospheric Chemistry 65 (1), 13-35.

Jardine, A. B., Jardine, K. J., Fuentes, J. D., Martin, S. T., Martins, G., Durgante, F., Carneiro, V., Higuchi, N., Manzi, A. O., Chambers, J. Q., 2015. Highly reactive lightdependent monoterpenes in the Amazon: Amazon light-dependent monoterpenes. Geophysical Research Letters 42.

Jardine, K., Yaẽz Serrano, A., Arneth, A., Abrell, L., Jardine, A., van Haren, J., Artaxo, P., Rizzo, L. V., Ishida, F.Y., Karl, T., Kesselmeier, J., Saleska, S., Huxman, T., 2011. Within-canopy sesquiterpene ozonolysis in Amazonia. Journal of Geophysical Research 116, D19301.

Kirchhoff, V. W. J. H., da Silva, I. M. O., Browell, E. V., 1990. Ozone measurements in Amazonia: Dry season versus wet season. Journal of Geophysical Research 95 (D10), 16913-16926.

Kuhn, U., Ganzeveld, L., Thielmann, A., Dindorf, T., Schebeske, G., Welling, M., Sciare, J., Roberts, G., Meixner, F. X., Kesselmeier, J., Lelieveld, J., Kolle, O., Ciccioli, P., Lloyd, J., Trentmann, J., Artaxo, P., Andreae, M. O., 2010. Impact of Manaus City on the Amazon Green Ocean atmosphere: Ozone production, precursor sensitivity and aerosol load. Atmospheric Chemistry and Physics 10 (19), 9251-9282.

Machado, L. a. T., Laurent, H., Dessay, N., Miranda, I., Apr. 2004. Seasonal and diurnal variability of convection over the Amazonia: A comparison of different vegetation types and large scale forcing. Theoretical and Applied Climatology 78 (1-3), 61-77.

Machado, L. a. T., Rossow, W. B., Guedes, R. L., Walker, A. W., Jun. 1998. Life cycle variations of mesoscale convective systems over the Americas. Monthly Weather Review 126 (6), 1630-1654.

Marques Filho, A. d. O., Dallarosa, R. G., Pacheco, V. B., 2005. Radiação solar e distribuição 
vertical de área foliar em floresta - Reserva Biológica do Cuieiras - ZF2, Manaus. Acta Amazonica 35 (4), 427-436.

Martin, S. T., Andreae, M. O., Althausen, D., Artaxo, P., Baars, H., Borrmann, S., Chen, Q., Farmer, D. K., Guenther, A., Gunthe, S. S., Jimenez, J. L., Karl, T., Longo, K., Manzi, A., Müller, T., Pauliquevis, T., Petters, M. D., Prenni, A. J., Pöschl, U., Rizzo, L. V., Schneider, J., Smith, J. N., Swietlicki, E., Tota, J., Wang, J., Wiedensohler, A., Zorn, S. R., 2010a. An overview of the Amazonian Aerosol Characterization Experiment 2008 (AMAZE-08). Atmospheric Chemistry and Physics 10 (23), 11415-11438.

Martin, S. T., Andreae, M. O., Artaxo, P., Baumgardner, D., Chen, Q., Goldstein, A. H., Guenther, A., Heald, C. L., Mayol-Bracero, O. L., McMurry, P. H., Pauliquevis, T., Pöschl, U., Prather, K. A., Roberts, G. C., Saleska, S. R., Silva Dias, M. A., Spracklen, D. V., Swietlicki, E., Trebs, I., 2010b. Sources and properties of Amazonian aerosol particles. Reviews of Geophysics 48 (2), RG2002.

Paulson, S. E., Chung, M., Sen, A. D., Orzechowska, G., 1998. Measurement of OH radical formation from the reaction of ozone with several biogenic alkenes. Journal of Geophysical Research 103 (D19), 25533-25539.

Paulson, S. E., Orlando, J. J., 1996. The reactions of ozone with alkenes: An important source of HOx in the boundary layer. Geophysical Research Letters 23 (25), 3727-3730.

Pickering, K. E., Thompson, A. M., Wang, Y., Tao, W.-K., McNamara, D. P., Kirchhoff, V. W. J. H., Heikes, B. G., Sachse, G. W., Bradshaw, J. D., Gregory, G. L., Blake, D. R., 1996. Convective transport of biomass burning emissions over Brazil during TRACE A. Journal of Geophysical Research 101 (D19), 23993-24012.

Rickard, A. R., Johnson, D., McGill, C. D., Marston, G., 1999. OH yields in the gas-phase reactions of ozone with alkenes. The Journal of Physical Chemistry A 103 (38), 7656-7664.

Sahu, L. K., Lal, S., 2006. Changes in surface ozone levels due to convective downdrafts over the Bay of Bengal. Geophysical Research Letters 33, L10807. 
Scala, J. R., Garstang, M., Tao, W.-k., Pickering, K. E., Thompson, A. M., Simpson, J., Kirchhoff, V. W. J. H., Browell, E. V., Sachse, G. W., Torres, A. L., Gregory, G. L., Rasmussen, R. A., Khalil, M. a. K., 1990. Cloud draft structure and trace gas transport. Journal of Geophysical Research 95 (D10), 17015-17030.

Sigler, M., J., Fuentes, J. D., Heitz, C., R., Garstang, M., Fisch, G., 2002. Ozone dynamics and deposition processes at a deforested site in the Amazon Basin. AMBIO 31 (1), 21-27.

Thompson, A. M., Tao, W.-K., Pickering, K. E., Scala, J. R., Simpson, J., 1997. Tropical deep convection and ozone formation. Bulletin of the American Meteorological Society 78 (6), 1043-1054.

Torres, A. L., Buchan, H., 1988. Tropospheric nitric oxide measurements over the Amazon Basin. Journal of Geophysical Research 93 (D2), 1396-1406.

Tóta, J., Fitzjarrald, D. R., da Silva Dias, M. A. F., 2012. Amazon rainforest exchange of carbon and subcanopy air flow: Manaus LBA site-A complex terrain condition. The Scientific World Journal 2012, 1-19.

Yuter, S. E., Houze, R. A., 1995. Three-dimensional kinematic and microphysical evolution of Florida cumulonimbus. Part II: Frequency distribution of vertical velocity, reflectivity, and differential reflectivity. Monthly Weather Review 123, 1941-1963.

Zhang, R., Tie, X., Bond, D. W., 2003. Impacts of anthropogenic and natural NOx sources over the U.S. on tropospheric chemistry. Proceedings of the National Academy of Sciences 100 (4), 1505-1509.

Zipser, E. J., 1969. The role of organized unsaturated convective downdrafts in the structureand rapid decay of an equatorial disturbance. Journal of Applied

Zipser, E. J., 1977. Mesoscale and Convective-Scale downdrafts as distinct components of squall-line structure. Monthly Weather Review 105 (12), 1568-1589. 